
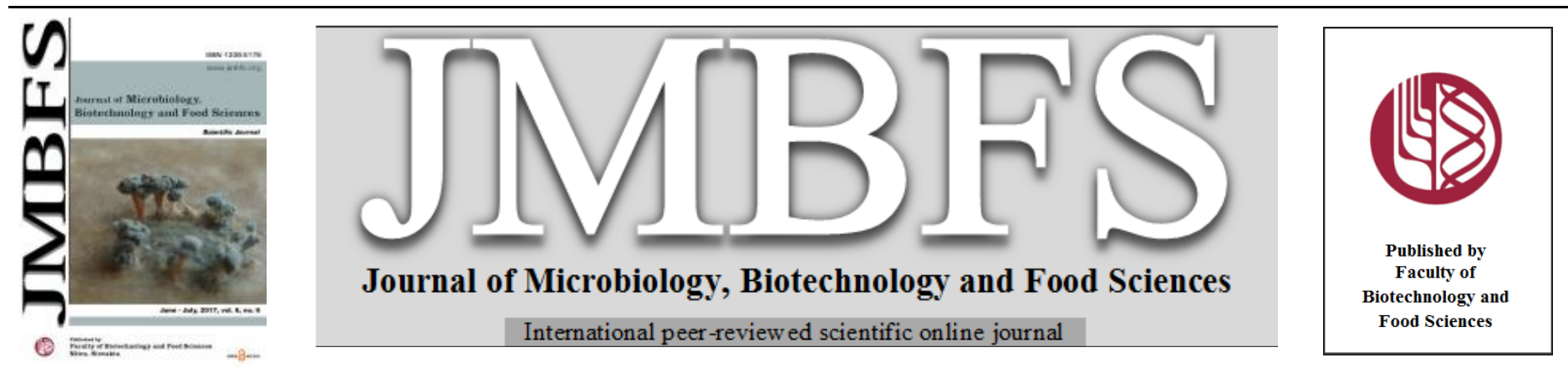

\title{
IN VITRO CHARACTERIZATION OF LACTIC ACID BACTERIA ISOLATED FROM LASODA BARI- A RARE FERMENTED FOOD OF HIMACHAL PRADESH-INDIA FOR POTENTIAL PROBIOTIC ATTRIBUTES
}

\author{
Anupama Gupta* and Nivedita Sharma
}

Address(es):

Microbiology Research Laboratory, Department of Basic Sciences, Dr. Y. S. Parmar University of Horticulture and Forestry, Nauni, Solan 173 230, (HP) India.

*Corresponding author: npm.gpt@gmail.com

doi: $10.15414 /$ jmbfs.2017.6.6.1323-1328

\section{ARTICLE INFO}

Received 15. 1.2016

Revised 9. 4. 2017

Accepted 27. 4. 2017

Published 1. 6. 2017

Regular article open $\partial$ access

\begin{abstract}
Probiotic lactic acid bacteria (LAB) are health promoting microorganisms which are recently been used as food additives and therapeutic supplements. Recently, there has been an increase of interest regarding the commercial utilization of probiotic LAB strains isolated from traditional and naturally fermented food products. Therefore, the present study was aimed to isolate and screen lactic acid bacteria from Lasoda bari - a rare fermented food of Himachal Pradesh, for the first time for their probiotic potential. Total eight isolates were obtained out of which one isolate was selected based on its broadest antagonistic spectrum. This strain was identified using 16S rRNA technique as Pediococcus pentosaceus LB-CC. The analysis of acid resistance, bile tolerance, antibiotic sensitivity, autoaggregation and microbial adhesion to organic solvents were established. The results revealed normal growth of $P$. pentosaceus LB-CC in the presence of low $\mathrm{pH}$, high bile salt concentration and ability to produce antimicrobial compounds. No gelatinase and DNase enzyme activity was detected. Natural susceptibility to the tested antibiotics was observed. Thus, according to these results, this probiotic strain could be proposed as safe potential probiotic culture and can be exploited for the production of nutraceutical agents.
\end{abstract}

Keywords: Probiotics, lasoda bari, lactic acid bacteria, Pediococcus, Himachal Pradesh, safety

\section{INTRODUCTION}

Health-promoting bacteria commonly referred to as probiotics, have been shown to improve the intestinal microbial balance and the properties of the indigenous microflora (Mattila-Sandholm et al.,1999). Probiotics are defined as 'Live microorganisms which when administered in adequate amounts confer a health benefit on host' (FAO/WHO, 2002). The term probiotics refers to viable, nonpathogenic microorganisms (bacteria or yeasts) that, when ingested, are able to reach the intestine in sufficient numbers to deliver health benefits to the host (Hawaz, 2014). Lactic acid bacteria (LAB) are one of the groups of microorganisms that dominate fermented foods and are potential probiotic candidates (Guasch-Jane $\boldsymbol{e t}$ al., 2005). LABs are widely used as in a variety of food preparations including dairy, meat and vegetables (Silva et al., 2013). The species belonging to the group of LAB like Lactobacillus, Lactococcus, Pediococcus, Streptococcus, etc. and genus Bifidobacterium are the most commonly used probiotics (Soccol et al., 2011; Saad et al., 2013). Pediococcus are gram positive, coccus, being able to colonize the digestive tract and can prevent cardiovascular diseases, prevent harmful pathogens from accessing the gastrointestinal mucosa and provoke immune reactions (Nghe and Nguyen, 2014).

Isolation and screening of lactic acid bacteria from naturally fermented rare and novel food products have always been the most powerful means for obtaining useful cultures for scientific and commercial purposes. The proper selection and balance of lactic acid bacteria used for starter culture is critical for the manufacture of fermented food products with their desirable texture and flavor (Sanders, 2000). LAB are commonly used in most probiotics preparations due to being the desirable members of the intestinal microflora and thus beneficially amend the balance of intestinal microflora, inhibit the growth of harmful bacteria, promote good digestion, boost immune function and increase resistance to infection (Ahn et al., 2002). A potential probiotic bacterium must qualify certain selection criteria such as acid and bile stability, antimicrobial production and antagonistic activity and should be preferably of human origin.

Currently, traditional fermented products are receiving new attention for their health promoting and disease preventing/curing effects, i.e., probiotic significance. These probiotic strains are acid tolerant and may be adaptable to intestinal conditions and survive the passage through the gastrointestinal tract. This opens up the possibility to use potential probiotic strains from fermented food products other than those of animal origin that are commonly used (Lindstrom et al., 2012). The main objectives of this study were to screen novel LAB from Lasoda bari - a rare and traditional fermented food product of Himachal Pradesh for its safety by antibiotic susceptibility test, hemolysis, DNase and gelatinase enzyme production ability and assessment of probiotic qualities that include acid-bile tolerance, auto-aggregation, hydrophobicity and antagonistic potential.

\section{MATERIAL AND METHODS}

\section{Isolation of Lactic acid bacteria}

LAB strain was isolated from Lasoda bari - a rare and traditional fermented food product of Himachal Pradesh (shown in figure 1) using De Man Rogosa and Sharpe (MRS) broth (De Man et al., 1960) by serial dilutions method and incubated at $35{ }^{\circ} \mathrm{C}$ for $24-48 \mathrm{~h}$ anaerobically. Lasoda bari is traditionally prepared from Lasoda (Cordia dichotoma) and black gram (Vigna mungo) Lasoda bari prepared from Lasoda fruits, being rich many medicinal properties viz. anti-inflammatory, remedying the effects of an inflamed colon and liver, diuretic, anti-ulcer and antidiabetic properties have been explored for the first time to isolate rare and potential probiotic strains. Pure strains, as judged by microscopic observations for homogeneity of cellular morphology, were maintained in $30 \%$ glycerol at $4{ }^{\circ} \mathrm{C}$. In total 8 isolates were obtained and were further tested for Gram reaction, catalase test, cell morphology and antimicrobial activity. Isolates LB-CC was selected for further study on the basis of its antagonistic spectrum against spoilage and food borne pathogens by using $\mathrm{Bit} /$ disc method. On the basis of $16 \mathrm{~S}$ rRNA gene technique LB-CC was identified as Pediococcus pentosaceus. The sequences so obtained were submitted in National Center for Biotechnology Information (NCBI) to get an accession number. $P$. pentosaceus LB-CC registered under the accession number KM251460. 


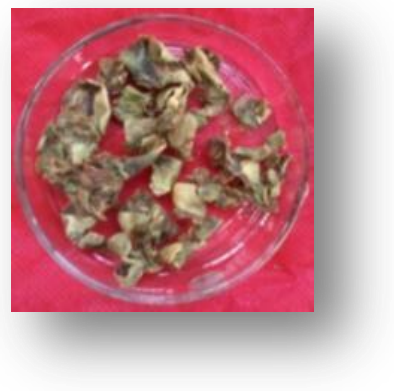

Figure 1 Lasoda bari

\section{Safety assessment of LAB}

One of the most important criteria for bacterial strains intended for use in the food industry is concern for their safety.

\section{Antibiotic susceptibility}

The antibiotic susceptibility was determined towards antibiotics viz. Ampicillin Augmentin, Gentamycin, Cephalosporin, Cloxacillin, Cefotaxime, Cefoxitin, Lincomycin, Tetracyclin, Amoxyclave, Co-trimoxazole and Cefuroxime Antibiotic-impregnated discs (Hi-media, India) were placed on seeded plates and the zone of growth inhibition was observed after $24 \mathrm{~h}$ of incubation at $35^{\circ} \mathrm{C}$ to detect their susceptibility for antibiotics.

\section{Hemolytic activity}

Hemolytic activity of selected isolate was determined by spot inoculating fresh overnight bacterial culture on Blood Agar plates (HiMedia) and incubated at 35 ${ }^{\circ} \mathrm{C}$ for $24-48 \mathrm{~h}$ (Linaje et al., 2004).

\section{DNase production}

DNase enzyme production of probiotic isolate was evaluated by following Gupta and Malik (2007). A clear pinkish zone around the colonies against dark blue background was considered as positive result for DNase enzyme production.

\section{Gelatinase production}

Gelatinase enzyme production of isolate was determined by streaking $24 \mathrm{~h}$ old culture on plates containing MRS agar supplemented with $3 \%$ gelatin. Development of clear zones around the colony against the opaque background indicated a positive reaction (Harrigan and McCance, 1990).

\section{Assessment of probiotic attributes:}

\section{Tolerance to Low Acid conditions}

To evaluate the low $\mathrm{pH}$ tolerance ability of the culture the method of Liong and Shah (2004) was followed with slight modifications. Buffers of different $\mathrm{pH}$ viz. $1,2,3$ and 6.5 were used to evaluate the tolerance of selected isolate for low $\mathrm{pH}$ for $3 \mathrm{~h}$. Acid tolerance was determined by comparing the final plate count after $3 \mathrm{~h}$ with the initial plate count at $0 \mathrm{~h}$

\section{Effect of bile salts on the growth rate of isolates}

Effect of bile on the growth of selected isolates was studied by the method Giililand and Walker (1990). Viability of cells in MRS broth supplemented with $0.3,1$ and $2 \%$ bile salts upto $8 \mathrm{~h}$ was observed by plating $100 \mu \mathrm{l}$ of culture onto MRS agar plates and incubated at $35{ }^{\circ} \mathrm{C}$ for $24 \mathrm{~h}$. Growth of bacteria was expressed in colony forming units per milliliter $(\log \mathrm{CFU} / \mathrm{ml})$ and the percent survival of strain was then calculated.

\section{Survival in simulated in vitro digestion}

Survival in simulated gastric and intestinal juice was determined following the method given by Charteris et al. (1998). The $\mathrm{pH}$ in human stomach ranges from 1 , during fasting, to 4.5 after a meal, and food ingestion can take up to 3-4 h. Thus, the tolerance was assayed by determining the viable count in simulated gastric juice after the incubation for different time intervals up to $4 \mathrm{~h}$. All the experiments were carried out in triplicates.

\section{Auto-aggregation}

Auto-aggregation assay was performed as described by Del Re $\boldsymbol{e t}$ al. (2000). Optical density (OD) of bacterial cells LB-CC suspended in phosphate buffer saline (PBS) was set to 0.5 at $600 \mathrm{~nm}$ followed by incubation at $35{ }^{\circ} \mathrm{C}$ for $5 \mathrm{~h}$ Auto-aggregation \% was measured as $1-(\mathrm{At} / \mathrm{A} 0) \times 100$, where At represents the absorbance at time $\mathrm{t}=1,2,3,4,5 \mathrm{~h}$ and $\mathrm{A} 0$ the absorbance at $\mathrm{t}=0 \mathrm{~h}$ (i.e. 0.5 )

\section{Co-aggregation}

Co-aggregation ability of selected isolated was determined by following the method described by Del Re et al. (2000). Mixtures were made for the selected isolate with pathogenic bacteria viz. Listeria monocytogenes MTCC 839, Clostridium perfringens MTCC 1739 and Bacillus cereus CRI at 1:1 ratio. Probiotic bacterial cells and indicator bacteria were kept as control and were incubated at $35{ }^{\circ} \mathrm{C}$ for $4 \mathrm{~h}$. Absorbance at $\lambda=600 \mathrm{~nm}$ was observed for mixture and each of individual strain. Co-aggregation \% was calculated according to Handley's equation (Handley et al., 1987).

\section{Antimicrobial activity}

Antimicrobial activity of cell free supernatant of isolate was checked against Listeria monocytogenes MTCC 839, Leuconostoc mesenteroides MTCC 107, Enterococcus faecalis MTCC 2729, Bacillus cereus CRI, Clostridium perfringens MTCC 1739, Pectobacterium carotovorum MTCC 1428 Escherichia coli IGMC, Pseudomonas syringae IGMC and Staphylococcus aureus IGMC. The well with the holding volume of $150 \mu \mathrm{L}$ was made in the center of the plate using well cutter. Samples of $24 \mathrm{~h}$ old cultures of isolate were centrifuged at $12,000 \mathrm{xg}$ for $10 \mathrm{~min}$, and $150 \mu \mathrm{L}$ of the supernatant was loaded in the well and the plates were incubated at $35^{\circ} \mathrm{C}$ for $24 \mathrm{~h}$ (Kimura et al., 1998). The antibacterial activity was determined and zones of inhibition were measured in millimeter ( $\mathrm{mm})$.

\section{$\mathrm{H}_{2} \mathrm{O}_{2}$ production}

Quantitative estimation of Hydrogen Peroxide $\left(\mathrm{H}_{2} \mathrm{O}_{2}\right)$ was done by following the method given in AOAC (1995).

\section{HPLC- determination of lactic acid}

As Pediococcus are homo-fermentative bacteria, major end product of their metabolism is lactic acid. Lactic acid production by $P$. pentosaceus LB-CC was detected by using HPLC (Novapak C-18) column, 490E multiwavelength UV detector, Millennium 2010 data processor and Rheodyne injector with $20 \mu 1$ loop. Mobile phase used was Methanol : Water (double distilled) (95: 5). Standard organic acid solution i.e. $5 \%$ of lactic acid (Sigma Aldrich) was prepared in double distilled water. HPLC analysis was firstly performed with standard organic solution followed by the samples. The monitoring was done at $210 \mathrm{~nm}$.

\section{RESULTS AND DISCUSSION}

\section{Isolation and biochemical characterization}

Eight Lactic acid bacteria isolates were obtained from Lasoda bari and 6 out of 8 were confirmed as rods while 2 were confirmed as coccus (tetrad) as revealed by microscopic examination, were non sporulating, catalase negative, not able to utilize citrate, no casein hydrolysis, no urease production and no indole production were observed. On the basis of microscopic examination isolates were tentatively identified as Lactobacillus and Pediococcus sp. Out of eight isolates LB-CC gave clear halos around the indicator pathogenic strains using bit/disc method with widest antimicrobial spectrum and was selected for further study. The largest diameter of inhibition upto $23.6 \mathrm{~mm}$ was obtained against serious food borne and spoilage pathogens viz. L. monocytogenes, S. aureus and C. perfringens, revealing their antagonistic potential and use as safe biopreservative. Similar antagonistic pattern was observed by Nghe and Nguyen (2014) where $P$. pentosaceus VTCC-B-601 showed effective antimicrobial effect against serious food borne pathogens Staphylococus aureus ATCC 25923, Salmonella typhimurium ATCC 19430, Pseudomonas aeruginosa ATCC 27853 and Micrococcus luteus ATCC 10240. Hawaz (2014) also studies the antimicrobial activity of Lactobacillus isolates against pathogentic bacteria viz. Staphylococcus sp., Bacillus sp., Pseudomonas sp. and E. coli and found them to show in vitro inhibitory zones.

Analysis of the 16S rRNA sequences revealed that lactic acid bacteria isolated from Lasoda bari displayed $99 \%$ homology with Pediococcus pentoseceus DSM 20336 as shown in figure 2 . The $16 \mathrm{~S}$ rRNA gene sequences were deposited in gene bank under accession no. KM251460 for Pediococcus pentoseceus LB-CC. Number of nodes in neighbor- joining phylogenetic tree are levels of bootstrap support $(\%)$ from 1000 resample database. The isolate has been reported for the very first time from Lasoda bari- a rare and novel fermented food product of Himachal Pradesh with a very good probiotic potential. 


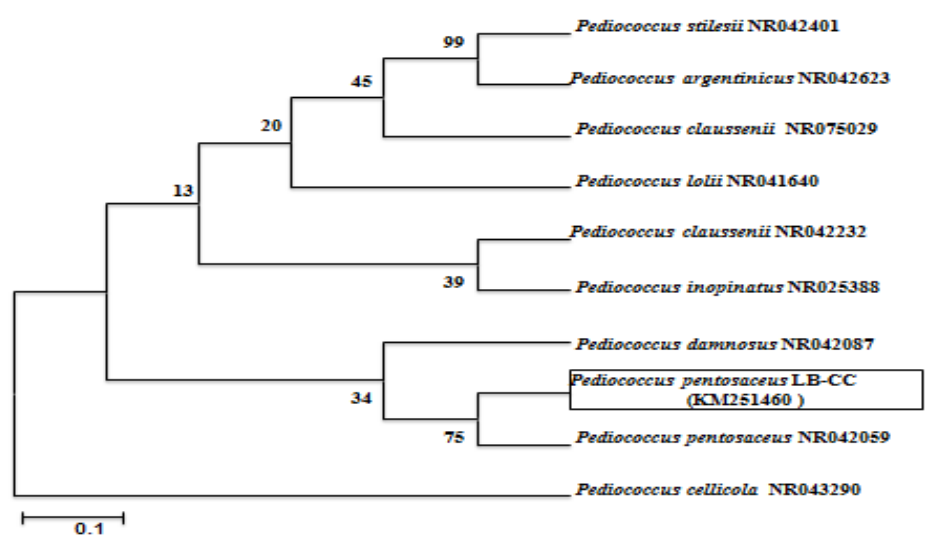

Figure 2 Neighbor joining phylogenetic tree of Pediococcus pentosaceus LBCC based on 16S rRNA gene sequence using Mega 6

\section{Safety assessment of isolates}

$P$. pentosaceus $\mathrm{LB}-\mathrm{CC}$ was found to be sensitive to all antibiotic used in the study (Tab 1), thereby presenting its inability to show resistance in the presence of antibiotics and thus their safe status. Isolate showed a negative response in the production of DNase and gelatinase enzymes as pathogenicity factors. No clear zones around colonies were observed on blood agar medium. Haemolytic activity would break down the epithelial layer while the gelatinase activity would damage the mucoid lining. Absence of haemolytic and gelatinase activity is a selection criterion for probiotic strains, indicating that these bacteria are non-virulent (Marroki and Bousmaha-Marroki, 2014).
Table 1 Antibiotic sensitivity of $P$. pentosaceus LB-CC

\begin{tabular}{lccc}
\hline S. & Antibiotics & Concentration $(\boldsymbol{\mu g})$ & $* \mathbf{S} / \mathbf{R}$ \\
\hline No & Ampicillin (AMP) & 30 & $\mathrm{~S}$ \\
1. & Augmentin (AMC) & 30 & $\mathrm{~S}$ \\
3. & Gentamicin (GEN) & 10 & $\mathrm{~S}$ \\
4. & Cephalothin (CEP) & 30 & $\mathrm{~S}$ \\
5. & Cloxacillin (COX) & 1 & $\mathrm{~S}$ \\
6. & Cefotaxime (CTX) & 30 & $\mathrm{~S}$ \\
7. & Cefoxitin (CX) & 30 & $\mathrm{~S}$ \\
8. & Lincomycin (L) & 2 & $\mathrm{~S}$ \\
9. & Tetracycline (TE) & 30 & $\mathrm{~S}$ \\
10. & Amoxyclav (AMC) & 30 & $\mathrm{~S}$ \\
11. & Co-trimoxazole & 25 & $\mathrm{R}$ \\
12. & Cefuroxime (CXM) & 30 & $\mathrm{~S}$ \\
$\%$ Sensitivity & & 91.66 \\
\hline \multicolumn{2}{l}{ Legend: } & S-Sensitive (Inhibited bacterial growth), R- Resistant (No effect on bacterial
\end{tabular}
growth)

\section{Acid and bile tolerance}

To be a successful probiotic, a bacterial strain must resist harsh conditions in stomach and gut region and must be able to colonize intestinal epithelium for it probiotic action. In this study we were able to obtain isolate that was able to grow even at $\mathrm{pH} 1$ (during fasting) (Tab 2). P. pentosaceus LB-CC tested for survival in acidic environment at varied $\mathrm{pH}$ levels showed ability to grow well even at the minimum tested $\mathrm{pH}$ of 1.0 for 60 and $120 \mathrm{~min}$ of incubation, respectively. Since the lactic acid bacteria produce lactic acid during their fermentative metabolism, it is a known fact that they would be able to survive in gut's acidic environment However, the acidic $\mathrm{pH}$ inside the gut would be from 2-4 in normal conditions (during fasting it may reach up to $\mathrm{pH} 1$ ), the organisms that could effectively survive the lowest possible $\mathrm{pH}$ are more preferred for use in the food preparations (Subhashini, 2014). Therefore, in the present study, tolerance to low $\mathrm{pH}$ by $P$. pentosaceus $\mathrm{LB}-\mathrm{CC}$ revealed its survival best under acidic conditions.

Table 2 Acid tolerance of $P$. pentosaceus LB-CC

\begin{tabular}{|c|c|c|c|c|c|c|c|c|c|}
\hline \multirow{3}{*}{ pH } & \multicolumn{9}{|c|}{ Incubation time (min) } \\
\hline & \multicolumn{5}{|c|}{ Cell survival $(\log \mathrm{CFU} / \mathrm{ml})^{*}$} & \multicolumn{4}{|c|}{$* * \%$ Cell Survival } \\
\hline & $\mathbf{0}$ & 60 & 120 & 180 & Mean & 60 & 120 & 180 & Mean \\
\hline 1.0 & 9.90 & 7.30 & 0.00 & 0.00 & 4.30 & $\begin{array}{c}71.77 \\
(57.88)^{\#}\end{array}$ & $0.00(0.00)$ & $0.0(0.00)$ & $\begin{array}{c}23.92 \\
(19.29)\end{array}$ \\
\hline 2.0 & 9.90 & 7.60 & 7.30 & 7.00 & 7.95 & $\begin{array}{c}74.47 \\
(59.63)\end{array}$ & $\begin{array}{c}71.50 \\
(57.71)\end{array}$ & $\begin{array}{c}68.2 \\
(55.65)\end{array}$ & $\begin{array}{c}71.39 \\
(57.66)\end{array}$ \\
\hline 3.0 & 10.00 & 10.05 & 9.80 & 9.60 & 9.86 & $\begin{array}{c}98.80 \\
(83.71)\end{array}$ & $\begin{array}{c}96.07 \\
(78.53)\end{array}$ & $\begin{array}{c}93.65 \\
(75.37)\end{array}$ & $\begin{array}{c}96.17 \\
(79.20)\end{array}$ \\
\hline Control & 10.14 & 10.17 & 10.20 & 10.25 & 10.19 & $\begin{array}{c}100 \\
(89.96)\end{array}$ & $100(89.96)$ & $\begin{array}{c}100 \\
(89.96)\end{array}$ & $100(89.96)$ \\
\hline Mean & 9.98 & 8.78 & 6.82 & 6.71 & & $\begin{array}{c}86.26 \\
(72.79)\end{array}$ & $\begin{array}{c}66.89 \\
(56.55)\end{array}$ & $\begin{array}{c}65.46 \\
(55.24)\end{array}$ & \\
\hline $\mathrm{CD}_{0.05}$ & \multicolumn{5}{|c|}{$\begin{array}{c}\text { Treatment }(\mathrm{T})=0.495 \\
\text { Incubation Time }(\mathrm{I})=0.495 \\
\text { TxI }=0.991\end{array}$} & \multicolumn{4}{|c|}{$\begin{array}{c}\text { Treatment }(\mathrm{T})=0.229 \\
\text { Incubation Time }(\mathrm{I})=0.198 \\
\text { TxI }=0.396\end{array}$} \\
\hline
\end{tabular}

The toxic effects of bile on bacterial cells are not well understood, but bile salts are surface-active, amphipathic molecules with a potent antimicrobial activity and they act as detergents that disrupt biological membranes (Lebeer et al. 2008). The physiological concentration of bile salts in the small intestine is between $0.2-2.0 \%$ (Gunn, 2000). In this study, concentrations of $0.3,1.0$ and $2.0 \%$ bile salts were used and effect of bile salt concentration on growth rate of isolate was studies. The culture when grown in $0.3,1.0$ and $2.0 \%$ of bile salt concentration showed $95.04,91.61$ and $91.33 \%$ survival on $8 \mathrm{~h}$ incubation as depicted in figure 3 . The decrease in viable cells was observed when the concentration of bile salt was increased upto $2.0 \%$. It was considered that bile salt causes the increase in permeability of bacterial cell membranes, as the membranes are composed of lipids and fatty acids.

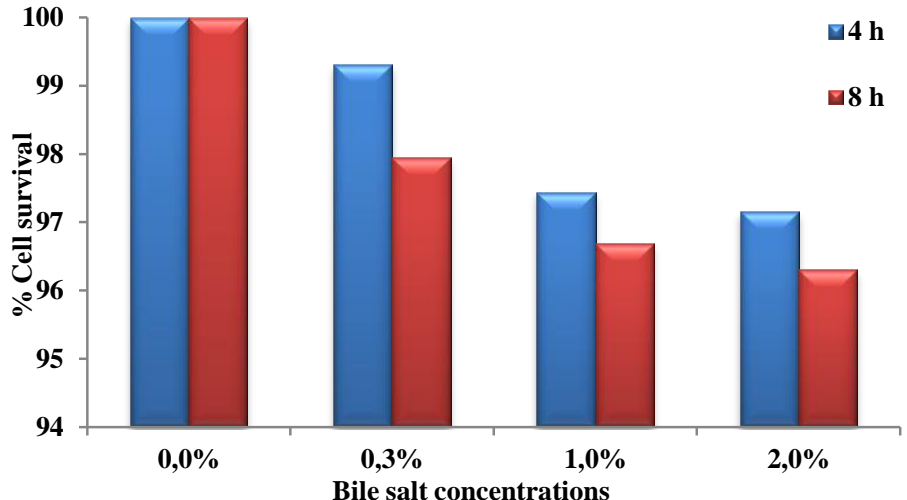

Figure 3 Bile salt tolerance of $P$. pentosaceus LB-CC

Tolerance to simulated gastric conditions

Gastrointestinal tract is the main location where the viability of lactic acid bacteria gets affected and the ability to survive in GI tract is one of the main desirable characteristics required for a probiotic. The survival of $P$. pentosaceus LB-CC at $\mathrm{pH}$ 2.0, 3.0 containing pepsin (depicting stomach conditions) and $\mathrm{pH}$ 8.0 containing pancreatin (depicting intestinal conditions) was observed for $4 \mathrm{~h}$. 
P. pentosaceus LB-CC exhibited good survival at $\mathrm{pH} 3(5.99 \log \mathrm{CFU} / \mathrm{ml})$ upto 4 $\mathrm{h}$ and retained a moderate rate of survival at $\mathrm{pH} 2.0(5.24 \log \mathrm{CFU} / \mathrm{ml})$ after $1 \mathrm{~h}$ of incubation (Tab 3). The results indicate that $P$. pentosaceus $\mathrm{LB}-\mathrm{CC}$ may resist the effects of pepsin and pancreatin during the gastrointestinal (GI) transit therefore could be the potential source for probiotic formulations with effective delivery in GI tract.

Table 3 Percent survival of $P$. pentosaceus $\mathrm{LB}-\mathrm{CC}$ in simulated gastric and intestinal juices

\begin{tabular}{|c|c|c|c|c|c|c|c|}
\hline \multirow{3}{*}{$\begin{array}{l}\text { Gastro- } \\
\text { intestinal } \\
\text { juices }\end{array}$} & \multicolumn{7}{|c|}{ Incubation Time (h) } \\
\hline & \multicolumn{4}{|c|}{ Cell survival (log CFU/ml) } & \multicolumn{3}{|c|}{ Cell survival (\%) } \\
\hline & $\mathbf{0}$ & 1 & 4 & Mean & 1 & 4 & Mean \\
\hline pH 2 & 9.8 & 5.2 & 0.0 & 5.00 & $49.61(44.76)^{\#}$ & $0.00(0.00)$ & $24.80(22.38)$ \\
\hline pH3 & 9.43 & 7.70 & 5.99 & 7.70 & $73.47(58.97)$ & $56.29(48.59)$ & $64.88(53.78)$ \\
\hline pH8 & 10.19 & 9.9 & 8.0 & 9.36 & $94.46(76.35)$ & $75.18(60.09)$ & $84.82(68.22)$ \\
\hline Control & 10.25 & 10.48 & 10.64 & 10.45 & $100(89.96)$ & $100(89.96)$ & $100(89.96)$ \\
\hline Mean & 9.91 & 8.32 & 6.15 & & $79.38(67.51)$ & $57.86(49.66)$ & \\
\hline $\mathrm{CD}_{0.05}$ & & $\begin{array}{r}\text { Treatn } \\
\text { Incubatio } \\
\mathrm{T}\end{array}$ & $\begin{array}{l}=0.036 \\
(\mathrm{I})=0.032 \\
63\end{array}$ & & & $\begin{array}{c}\text { Treatment }(\mathrm{T})=0.005 \\
\text { Incubation Time }(\mathrm{I})=0.004 \\
\text { TxI }=0.007\end{array}$ & \\
\hline
\end{tabular}

\section{Auto-aggregation and Co-aggregation}

Auto-aggregation was investigated on the basis of sedimentation characteristics and has been shown in figure 4 . The sedimentation rate of isolates was measured over a period of $5 \mathrm{~h}$. Results showed that $P$. pentosaceus LB-CC exhibited strong auto-aggregating ability ( $99 \%$ ). Better growth of the bacteria on MRS broth than on MRS agar could be the reason for slightly better auto-aggregation of cells grown on MRS broth. The observed auto-aggregation could be related to cell surface component, because it was not lost after washing and suspending of the cells in phosphate buffer saline (PBS) Kos et al., 2003).

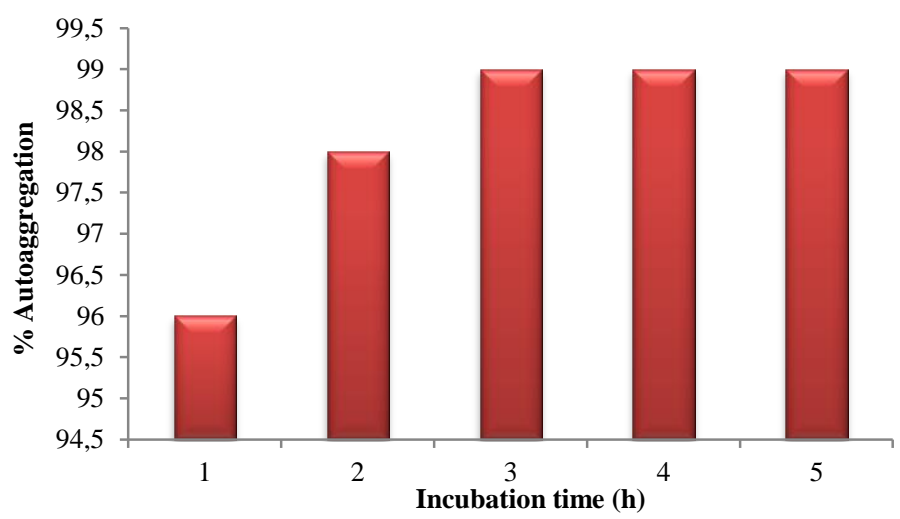

Figure 4 Auto-aggregation ability of $P$. pentosaceus LB-CC

Probiotic and pathogenic bacteria can combine together called co-aggregation. Probiotics are able to co-aggregate with pathogens and will efficiently inhibit and kill pathogenic bacteria as antimicrobial compounds can move directly on pathogens. $P$. pentosaceus LB-CC exhibited co-aggregative properties with all the pathogenic strains tested after $4 \mathrm{~h}$ incubation at $35{ }^{\circ} \mathrm{C}$. The ability of $P$. pentosaceus LB-CC to co-aggregate with B. cereus $(19.0 \%)$ was significantly better than that with other two pathogenic strains viz. L. monocytogenes and $C$. perfringens (18.36 and $8.16 \%$,respectively) tested (figure 5).

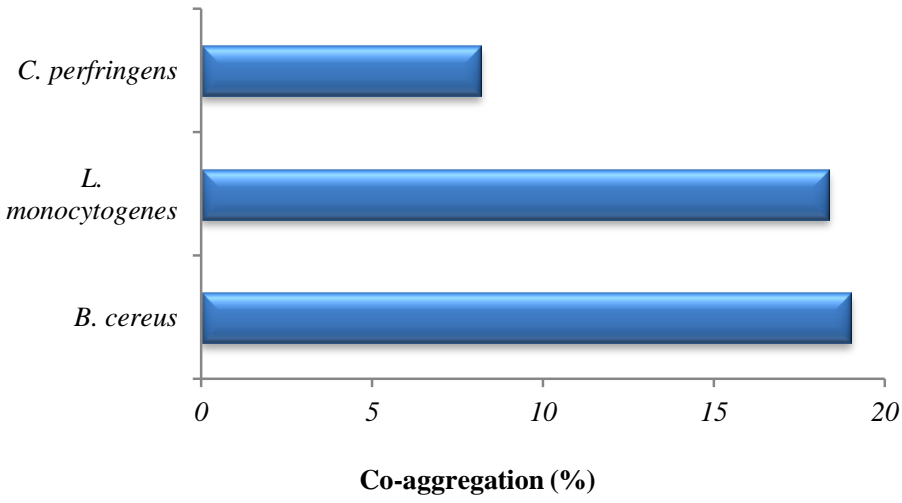

Figure 5 Co-aggregation ability of $P$. pentosaceus LB-CC with pathogens

\section{Antimicrobial potential}

\section{Lactic acid production}

$P$. pentosaceus LB-CC was able to inhibit the tested indicator organisms with varied zones of inhibition. The inhibitory activity of strains against pathogenic bacteria is shown in figure 6. Some species of Staphylococcus aureus, Enetrococcus, Leuconostoc and Listeria are highly pathogenic to human beings The isolated $P$. pentosaceus LB-CC showed strong bactericidal activity against these species. Probiotic bacteria exhibited inhibitory zones against pathogenic bacteria in the range of $14.6-24.5 \mathrm{~mm}$ showing high inhibitory activity $(>10 \mathrm{~mm})$ (Savagado et al., 2004). All this indicated a quite broad antagonistic spectrum of the strains.

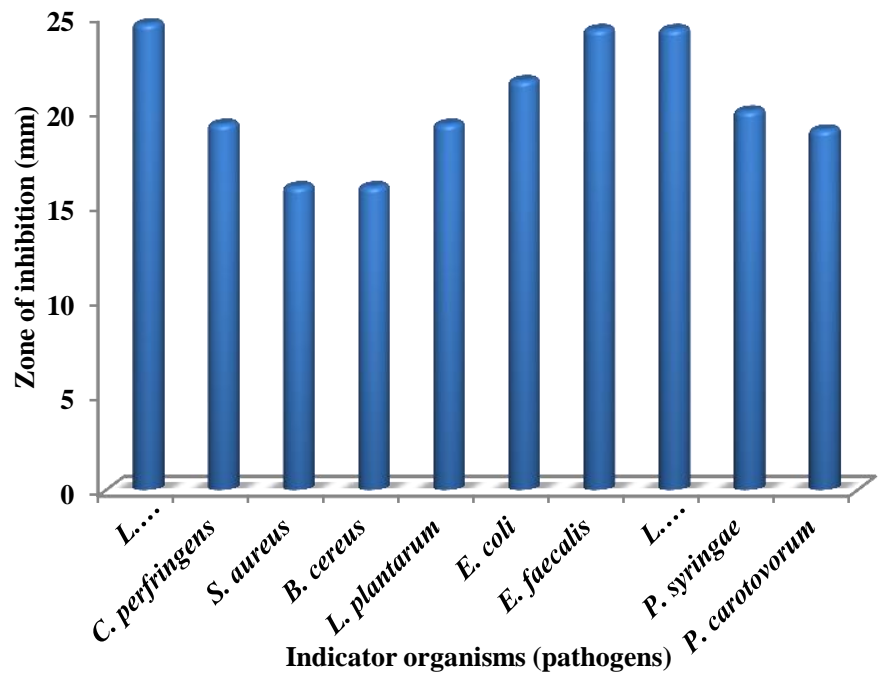

Figure 6 Antimicrobial activity of $P$. pentosaceus LB-CC against indicator strains at un-neutralized $\mathrm{pH}$

The $\mathrm{pH}$ and titratable acids in the cell free culture supernatant of $P$. pentosaceus LB-CC and were 3.43 and $0.09 \%$, respectively. Pediococcus are homofermentative bacteria which produce more than $85 \%$ lactic acid from glucose being the major product of fermentation. P. pentosaceus LB-CC was homofermentative culture for lactic acid production which was quantified by HPLC system (Novapak C-18) and has been found to be $7.844 \mathrm{mg} / \mathrm{L}$, after $24 \mathrm{~h}$ of incubation. Figure 7 shows typical HPLC chromatogram of standard and lactic acid extracted from culture supernatant of $P$. pentosaceus LB-CC revealing their antimicrobial potential. 

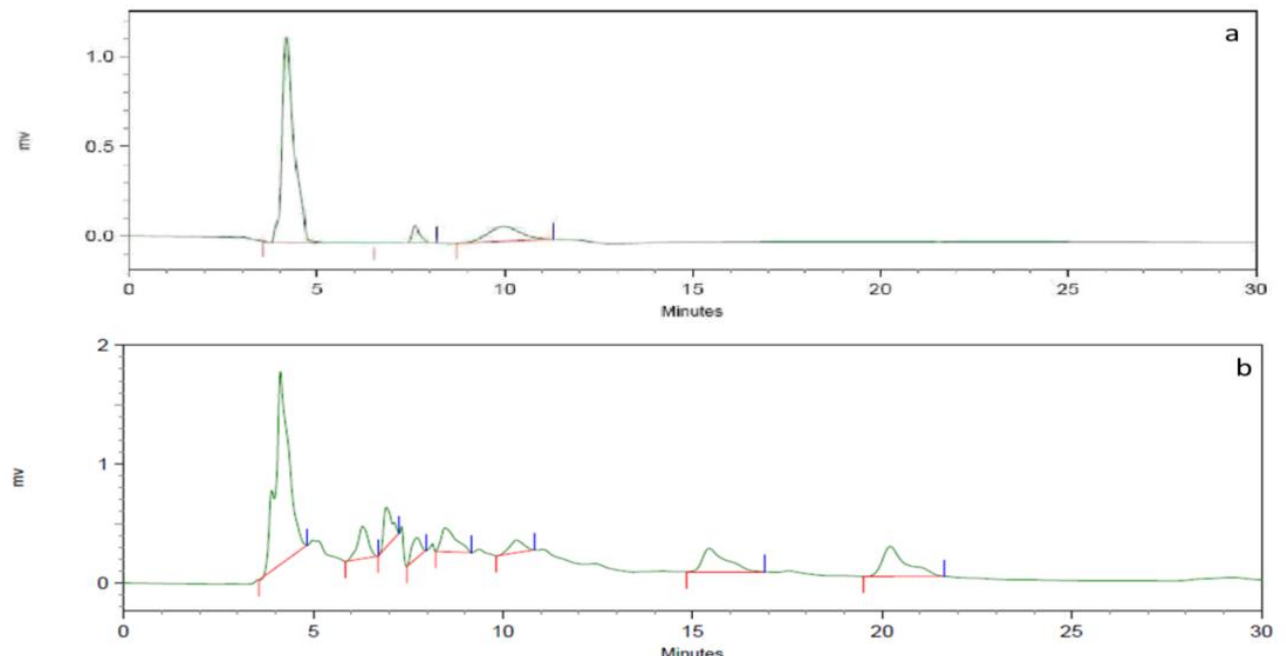

Figure 7 HPLC Chromatogram of a) standard solution of lactic acid b) culture supernatant of $P$. pentosaceus LB-CC

The antimicrobials secreted by lactic acid bacteria are mainly organic acids produced from the fermentation of sugars, which leads to the typical low $\mathrm{pH}$ of fermented foods. This low $\mathrm{pH}$ is able to inhibit the growth of most pathogens (Boskey et al., 2001). Ribeiro et al. (2014) estimated lactic acid concentration produced by Pediococcus acidilactici B14 which was found to be $1.1 \%$ and responsible for the antimicrobial potential of the strain. Vodnar et al. (2010) evaluated lactic acid production by probiotic bacteria on model MRS medium during fermentation processes using HPLC and found that probiotic bacteria viz. Lactobacillus plantarum achieved lactic acid concentration close to $6.08 \mathrm{~g} \mathrm{~L}^{-1}$ Lactobacillus casei $6.16 \mathrm{~g} \mathrm{~L}^{-1}$, Bifidobacterium infantis $7.09 \mathrm{~g} \mathrm{~L}^{-1}$ and Bifidobacterium breve $6.17 \mathrm{~g} \mathrm{~L}^{-1}$ after $78 \mathrm{~h}$ of fermentation resulting to their antimicrobial potential.

\section{Bacteriocin production}

The bacteriocin activity of the probiotic isolate was evaluated by assaying serial two-fold dilutions of acid neutralized and catalase treated culture filtrate supernatant (CFS) against L. monocytogenes and maximum bacteriocin production was observed at $18 \mathrm{~h}$ of growth cycle with $666 \mathrm{AU} / \mathrm{ml}$ activity units rendering its potential to be used as a safe and efficient bio-preservative as compared to harmful chemical preservative in food product. As the activity was lost after treatment with trypsin, this suggests that the activity was caused by bacteriocin produced by the isolates.

\section{$\mathrm{H}_{2} \mathrm{O}_{2}$ production}

Probiotic isolates $P$. pentosaceus LB-CC was screened for $\mathrm{H}_{2} \mathrm{O}_{2}$ production and has been reported to produce $0.52 \mathrm{~g} \mathrm{~L}^{-1}$. Hydrogen peroxide is normally produced by vaginal lactobacilli isolates, but may also be associated with intestinal lactobacilli or those living in the environment (Pascual et al., 2006; Martin and Suarez, 2010). This trait is rarely reported in probiotic LAB isolated from fermented food products. In this study, P. pentosaceus LB-CC has been reported for the first time to produce $\mathrm{H}_{2} \mathrm{O}_{2}$ as an antimicrobial agent against food spoilage pathogens. Thus, this trait may be beneficial in improving vaginal health and in preventing urinogenital infections.

On the basis of these results, it can be hypothesized that the antagonistic activity of this strain relies on acidity, lactic acid, $\mathrm{H}_{2} \mathrm{O}_{2}$ and other antimicrobia compounds (bacteriocins), thus revealing its potential and safe use as biopreservative agents in food and fermentation industry. Efficacy and effectiveness of antimicrobial potential of Pediococcus spp. have been studied widely. Mandal et al. (2008) studied the antagonistic potential of P. acidilactici LAB5 against some food spoilage and human pathogenic bacteria and proved the antagonistic efficacy of antibacterial substance secreted by the strain i.e. bacteriocin against pathogenic bacteria viz. Listeria, Staphylococcus, Streptococcus, Enterococcus and Leuconostoc. P. pentosaceus $2 \mathrm{~A} 2$ and $1 \mathrm{~A} 6$ isolated from Indonesian local beef exhibited antibacterial activity against $E$. col ATCC25922, EPEC, S. typhimurium ATCC14028 and S. aureus ATCC25923 (inhibition zones 5.5-14 mm) (Arief et al., 2015).

\section{CONCLUSION}

Pediococcus pantosaceus LB-CC isolated from Lasoda bari has been evaluated for its probiotic potential and was found resistance to low $\mathrm{pH}$ and bile salts $(0.3 \%)$ and simulated gastric and intestinal conditions, was able to produce bacteriocin and lactic acid against a number of serious food borne and spoilage causing microorganisms. The susceptibility to selected eleven antibiotics, inability to produce gelatinase and DNase and non-hemolytic nature revealed its safe status for further use in food and fermentation industry. However, further evaluation of its beneficial health effects on human beings will boost the application of the strains in food and pharmaceutical industry.

\section{REFERENCES}

AHN, Y.T., LIM, K.L., RYU, J.C., KANG, D.K., HAM, J.S., JANG, Y.H., KIM H.U. 2002. Characterization of Lactobacillus acidophilus isolated from piglets and chicken. Asian Journal of Animal Science, 15(12), 1790-1797. http://dx.doi.org/10.5713/ajas.2002.1790

AOAC. 1995. Official methods of analysis of association of official analytica chemists, $16^{\text {th }}$ edn. Vol I and II. Association of Official Analytical Chemists. Arlington, Virginia, USA.

ARIEF, I.I., JENIE, B.S.L., ASTAWAN, M., FUJIYAMA, K., WITARTO, A.B 2015. Identification and probiotic characteristic of lactic acid bacteria isolated from Indonesian local beef. Asian Journal of Animal Science, 9(1), 25-36. http://dx.doi.org/10.3923/ajas.2015.25.36

BOSKEY, E.R., CONE, R.A., WHALEY, K.J., MOENCH, T.R. 2001. Origins of vaginal acidity: high $\mathrm{D} / \mathrm{L}$ lactate ratio is consistent with bacteria being the primary source. Hum Reproduction, 16, 1809-1813. http://dx.doi.org/10.1093/humrep/16.9.1809

CHARTERIS, W.P., KELLY, P.M., MORELLI, L., COLLINS, J.K. 1998 Development and application of an in vitro methodology to determine the transit tolerance of potentially probiotics Lactobacilli and Bifidobacterium species in the upper human gastrointestinal tract. Journal of Applied Microbiology, 84, 759768. http://dx.doi.org/10.1046/j.1365-2672.1998.00407

DE MAN, J., ROGOSA, M., SHARPE, M. 1960. A medium for the cultivation of lactobacilli. Journal of Applied Bacteriology, 3,13-135. http://dx.doi.org/10.1111/j.1365-2672.1960.tb00188

DEL RE, B., SGORBATI, B., MIGLIOLI, M., PALENZONA, D. 2000. Adhesion, autoaggregation and hydrophobicity of 13 strains of Bifidobacterium longum. Letters in Applied Microbiology, 31, 438-442. http://dx.doi.org/10.1046/j.1365-2672.2000.00845

FAO/WHO. 2002. Guidelines for the evaluation of probiotics in food," London, Ontario. Food and Agriculture Organization of the United Nations and World Health Organization Working Group Report, pp. 1-11.

GILLILAND, S.E., WALKER, D.K. 1990. Factors to consider when selecting culture of $L$. acidophilus as a dietary adjunct to produce a hypercholesterolemic effect in humans. Journal of Dairy Science, 73, 905-909. http://dx.doi.org/10.3168/jds.S0022-0302(90)78747-4

GUASCH-JANE, M., ANDRES-LACUEVA, C., JAUREGUI, O., LAMUELARAVENTOS, R. 2005. First evidence of white wine in ancient Egypt from Tutankhamun's tomb. Journal of Archaeological Science, 33, 1075-1080. http://dx.doi.org/10.1016/j.jas.2005.11.012

GUNN, J.S. 2000. Mechanisms of bacterial resistance and response to bile Microbes Infection, 2, 907-913. http://dx.doi.org/10.1016/S1286-4579(00)00392

GUPTA, H., MALIK, R.K. 2007. Incidence of virulence in bacteriocin producing enterococcal isolates. Lait, 87, 587 601. http://dx.doi.org/10.1051/lait:2007031

HANDLEY, P.S., HARTY, D.W., WYATT, J.E., BROWN, C.R., DORAN, P., GIBBS, A.C. 1987. A comparison of the adhesion, coaggregation and cellsurface hydrophobicity properties of fibrillar and fimbriate strains of Streptococcus salivarius. Journal of General Microbiology, 133(11), 3207-3217. HARRIGAN, W.F., MC CANCE, M.E. 1990. Laboratory Methods in Food and Dairy Microbiology. Academic Press, London.

HAWAZ, E. 2014. Isolation and identification of probiotic lactic acid bacteria from curd and in vitro evaluation of its growth inhibition activities against 
pathogenic bacteria. African Journal of Microbiology Research, 8(13), 14191425. http://dx.doi.org/10.5897/AJMR2014.6639

KIMURA, H., SASHIHARA, T., MATSUSAKI, H., SONOMOTO, K., ISHIZAKI, A. 1998. Novel bacteriocin of Pediococcus sp. ISK-1 isolated from well - aged bed of fermented rice bran. Annals New York Academy of Science, 864, 345-348. http://dx.doi.org/10.1111/j.1749-6632.1998.tb10336

KOS, B., SUSKOVIC, J., VUKOVIC, S., SIMPRAGA, M., FRECE, J., MATOSIC, S. 2003. Adhesion and aggregation ability of probiotic strain Lactobacillus acidophilus M92. Journal of Applied Microbiology, 94, 981-987. http://dx.doi.org/10.1046/i.1365-2672.2003.01915

LEBEER, S., VANDERLEYDEN, J., DE KEERSMAECKER, S.C. 2008. Genes and molecules of lactobacilli supporting probiotic action. Microbiology and Molecular Biology $\quad$ Reviews, 72, 728-764. http://dx.doi.org/10.1128/MMBR.00017-08

LINAJE, R., COLOMA, M.D., PEREZ-MARTINEZ, G., ZUNIGA, M. 2004. Characterization of faecal enterococci from rabbits for the selection of probiotic strains. Journal of Applied Microbiology, 96, 761-771. http://dx.doi.org/10.1111/j.1365-2672.2004.02191

LINDSTROM, C., HOLST, O., NILSSON, L., OSTE, R., ANDERSSON, K.E. 2012. Effects of Pediococcus parvulus 2.6 and its exopolysaccharide on plasma cholesterol levels and inflammatory markers in mice. AMB Express, 2, 66 http://dx.doi.org/10.1186/2191-0855-2-66

LIONG, M.T., SHAH, N.P. 2004. Acid and bile tolerance and cholesterol removal ability of Lactobacilli strains. Journal of Dairy Science, 88, 55-56. http://dx.doi.org/10.3168/jds.S0022-0302(05)72662

MANDAL, V., SEN, S.K., MANDAL, N.C. 2008. Optimized culture conditions for bacteriocin production by Pediococcus acidilactici LAB 5 and its characterization". Indian Journal of Biochemistry and Biophysics, 45, 106-110.

MARROKI, A., BOUSMAHA-MARROKI, L. 2014. Lactobacilli isolated from Algerian goat's milk as adjunct culture in dairy products. Brazilian Archives of Biology and Technology, 57, 410-420. http://dx.doi.org/10.1590/S151689132014005000003

MARTIN, R., SUAREZ, J.E. 2010. Biosynthesis and degradation of $\mathrm{H}_{2} \mathrm{O}_{2}$ by vaginal lactobacilli. Applied and Environmental Microbiology, 76, 400-405. http://dx.doi.org/10.1128/AEM.01631-09

NGHE, D, NGUYEN, T. 2014. Characterization of antimicrobial activities of Pediococcus pentosaceus Vtcc-B-601. Journal of Applied Pharmaceutical Sciences, 4(05), 061-064. http://dx.doi.org/10.7324/JAPS.2014.40511

PASCUAL, L.M., DANIELE, M.B., PAJARO, C., BARBERIS, L. 2006 Lactobacillus species isolated from the vagina: identification, hydrogen peroxide production and nonoxynol-9 resistance. Contraception, 73, 78-81. http://dx.doi.org/10.1016/j.contraception.2005.06.066

RIBEIRO, M.C.O., VANDENBERGHE, L.P.S., SPIER, M.R., PALUDO, K.S SOCCOL, C.R., SOCCOL, V.T. 2014. Evaluation of probiotic properties of Pediococcus acidilactici B14 in association with Lactobacillus acidophilus ATCC 4356 for application in a soy based aerated symbiotic dessert. Brazilian Archives of Biology and Technology, 57(5), 755-765. http://dx.doi.org/10.1590/S1516-8913201402258

SAAD, N., DELATTRE, C., URDACI, M., SCHMITTER, J.M., BRESSOLLIER, P. 2013. An overview of the last advances in probiotic and prebiotic field. LWT - Food Science and Technology, 50(1), 1-16. http://dx.doi.org/10.1016/j.lwt.2012.05.014

SANDERS, M.E. 2000. Consideration for use of probiotic bacteria to modulate human health. Journal of Nutrition, 130, 384-390.

SAVAGADO, A., OUATTARA, C.A.T., BASSOLE, I.H.N., TRAORE, A.S 2004. Antimicrobial activities of lactic acid bacteria strains isolated from Burkina Faso fermented milk. Pakistan Journal of Nutrition, 3, 174-179.

SILVA, B.C., JUNG, L.R.C., SANDES, S.H.C., ALVIM, L.B., BOMFIM, M.R.Q., NICOLI, J.R., NEUMANN, E., NUNES, A.C. 2013. In vitro assessmen of functional properties of lactic acid bacteria isolated from fecal microbiota of healthy dogs for potential use as probiotic. Beneficial Microbes, 4(3), 267-275. http://dx.doi.org/10.3920/BM2012.0048

SOCCOL, C.R., DE SOUZA VANDENBERGHE, L.P., SPIER, M.R., MEDEIROS, A.B.P., YAMAGUISHI, C.T., DE DEA LINDNER, J., PAN, A., THOMAZ-SOCCOL, V. 2010. The potential of probiotics: A review. Food Technology, 48(4), 413-434.

SUBHASHINI. 2014. Bioprospecting of Lactic acid bacteria for potentiality as probiotics. International Journal of Microbiological Research, 5(2), 90-97. http://dx.doi.org/10.5829/idosi.ijmr.2014.5.2.83291

VODNAR, D.C., PAUCEAN, A., DULF, F.V., SOCACIU, C. 2010. HPLC characterization of lactic acid formation and FTIR fingerprint of probiotic bacteria during fermentation processes. Notulae Botanicae Horti Agrobotan 